\title{
Ecocide, the integrity of creation and the rights of the next generation
}

\author{
$\mathrm{J}^{\mathrm{M}}$ Vorster $^{1}$ \\ (North-West University - Potchefstroom Campus)
}

ABSTRACT

Ecocide, the integrity of creation and the rights of the next generation

Environmental Ethics is currently a highly important theme in Christian Ethics. This is due to the disturbing results of the current ecological research. Scholars today speak of "ecocide" - a term which describes the on-going destruction of ecosystems by means of pollution, deforestation, modern warfare, toxic waste and the increase in poverty. Of special concern is the accusation that Christianity with its emphasis on the dominium terrae is partly to blame for this state of affairs. This article investigates the magnitude of ecocide as well as the historical influences of Christianity. It focuses on a re-assessment of the Christian approach as well as the responsibilities of governments, educators, churches and corporations to take care of creation and the rights of the future generation.

\section{INTRODUCTION}

One of the most pressing issues facing Christian ethics today is the ecological crisis. The current burgeoning of literature in the fields of science, technology, philosophy and religion dealing with the pollution of the environment is sufficient evidence of an enormous problem facing humankind and nature. The destruction of the ecosystems due to the modern lifestyle poses a threat not only to living species but also to future generations. McCormick and Connors (2002:220) are correct in their assessment that in this age people not only have to take care of themselves but also of their descendants. The ecological crisis raises issues regarding the violation of the integrity of creation and the violation of the rights of future generations with regard to access to a habitable environment and clean water and air.

$1 \mathrm{~J}$ M Vorster is professor of Ethics, North-West University (Potchefstroom Campus). 
The assumption of this article is that humans are responsible for creation. But then it is important to note that caring for creation is not only about safeguarding the habitat of humankind. Caring for creation involves much more than just an anthropocentric approach and our actions today should be guided in such a way that both the integrity of creation and the rights of the future generations are safeguarded and honored. Based on this assumption this article reflects upon some of these issues from the perspective of a Christian environmental ethics. In modern times ethicists use the term "environmental ethics" which refers to duties to, and values in, the natural world. That is duties we humans have to sentient animals, plants, species, and ecosystems (Bouma-Prediger 2001:100).

History, and especially modern times, have been marked by a process that can be termed as "ecocide". Broswimmer (2002:109) uses this term to refer to the most recent crisis of the mass extinction of species. With the term ecocide he has the following in mind: "Acts undertaken with the intention of disrupting or destroying, in whole or in part, a human ecosystem. Ecocide includes the use of weapons of mass destruction, whether nuclear, bacteriological, or chemical; attempts to provoke natural disasters such as volcanoes, earthquakes, or floods; the military use of defoliants; the use of bombs to impair soil quality or to enhance the prospect of disease; the bulldozing of forests or croplands for military purposes; the attempt to modify weather or climate as a hostile act; and, finally, the forcible and permanent removal of humans or animals from their habitual place of habitation on a large scale to expedite the pursuit of military or other objectives. The concept of ecocide is analytically expanded here to describe contemporary holocaustic patterns of global environmental degradation and anthropogenic mass extinction of species".

A daily report of the effects of ecocide will provide the following information: "Also today as many as 100 animal and plant species have become extinct, some further 50000 hectares of tropical rainforests have disappeared: the deserts have expanded worldwide by another 20,000 hectares; the global economy has consumed today the equivalent of 22 million tons of oil and we will consequently have collectively released during the same 24 hours another 100 million tons of greenhouse gasses into the atmosphere" (Broswimmer 2002:5; see also Geisler 1989: 293). 
This is a very serious issue for the following reasons:

- The destruction of ecological systems and the consequent extinction of species contravene the cultural mandate given by God in Gen 1:27 - 30 .

- Damage to the ecosystem distorts the integrity of creation.

- $\quad$ Species depend on each other for their survival.

- Extinction of species is irreversible. Loss of species is final.

- Extinction of species distorts the richness and beauty of life on earth.

- Extermination of species impoverishes humanity spiritually and literally.

- Human well-being depends on the preservation of nature. Biological products and processes, for example, account for 45 per cent of the world economy, and the annual economic and environmental benefits of biodiversity in the United States alone total approximately $\$ 300$ billion.

\section{THE HISTORY OF ECOCIDE}

Broswimmer (2002:12) provides a valuable and well documented periodisation of ecocide. He indicates that three historical phases can be identified in the etiology of ecocide. The first critical step in the etiology of the present disaster occurred some 60000 years ago. The second critical step in the etiology of ecocide was the establishment of sedentary agriculture, culminating in the Neolithic revolution some 10000 years ago. The third critical step in the etiology of ecocide was the rise of modernity. McCormick and Connors (2002:218) roughly use the same periodisation with reference to Rasmussen. They use the following terminology: the land-based age, the industrial age and the ecological age.

For the purpose of this article the periodisation and terminology of Broswimmer will be used and the main factors which caused ecological disasters in each of these periods will be identified in the following outline with complementary information from other recent sources.

\subsection{The first phase}

Two factors played a pivotal role in this phase: 
- $\quad$ The use of extra somatic energy in the form of fire enabled Homo sapiens to exploit nature in an expanded way for the purpose of diet and hunting. More products could be consumed and more efficient weapons were developed in the quest for food and clothing. Hunting exceeded the limits of what was necessary for human survival and led to the extinction of many species in all the continents.

- The second defining marker of ecocide in this phase was the development of language and an unprecedented expansion of the human for culture and social organization. Culture and language expanded the range of human possibilities. The ability to communicate promoted, for example, the skills to hunt in a group and this added a further dimension in the destruction of the ecosystems. Due to its creative nature the development of culture was of course positive for the human life-style and human survival. However, it not only created but also destroyed: ecocide constitutes the destructive dimension of cultural evolution.

\subsection{The second phase}

The second phase started with the Neolithic revolution. This phase was introduced with the transition from hunting gathering to agricultural production. Agriculture resulted in gradual demographic and geographic expansion because of the constant depletion of local natural environments. Movements left behind land damaged by over exploitation as a result of primitive farming methods and salination because of their irrigation methods. Cities were deserted by their populations because the irrigated soil that has produced the world's first agricultural surpluses had become saline and waterlogged. A good example of this phenomenon occurred during the Bronze Age, several thousand years ago, in the valley of the Tigris and the Euphrates. Here, as a result of the over exploitation of land, dams and canals silted up, and the land became infertile due to water logging and salt accumulation. This ecological disaster led to the collapse of a whole civilization.

Other communities, for example, collapsed due to deforestation. A good example of the destruction of the ecosystems in this period was the abuse of natural resources in the Mediterranean. The demographic and economic expansion of the Greek city-states led to the continuous destruction of rich pine and 
oak forests due to the need for lumber and firewood. The Romans continued this process and their actions were motivated partly by their religious conviction that the planet was the property of humankind and should be exploited for human purposes.

The same pattern occurred in other parts of the world in the Neolithic Age. Broswimmer (2002:50) refers in this regard to the Chaco Anasazi in North America, the disasters in Northwestern New Mexico, the Mayas in Meso-america and the Easter Islanders in Rapa Nui.

\subsection{The third phase}

According to Broswimmer (2002:54) the third phase originated with the development of modernity. In modernity ecocide developed from a localized, regional phenomenon to a global problem. Initially this tendency was characterized by four related features: the increasing division of labor, the capitalist mode of production, the emergence of the modern nation-state and the process of colonization. Individual enterprise and commercial competition were promoted as the beneficial engines of progress and enlightenment. Capitalism envisioned a society where there should be a freedom to buy, to sell and to produce in abundance. The ever hungry machine of production and the quest for prosperity led to the conquest of other parts of the world. Colonization thus became a distinctive marker in the etiology of ecocide.

A significant example of the contribution of colonization in the etiology of ecocide is the demise of the buffalo in North America. The colonization of North America led to a growing trade in fur and beaver to Europe (Parent 2003:324). The buffalo was a very popular commodity. Sometimes 2500 buffalo were killed in a single hunt and this practice was welcomed by the Roman Catholic missionaries because they thought that the extinction of the buffalo would make their objects of mission less mobile (Parent 2003:330). When the fur trade declined, lumber became the chief export of Canada for Britain needed this lumber for masts of ships. In 1808 ten ship loads a day left British North America bound for Britain (Wilson 1988:126). Another example was the rise of commercial whaling. Similar acts of ecological destruction emerged with huge mining enterprises in the colonies, the world-wide sugar industry, deforestation and pollutions of rivers and lakes. 
The effect of modern warfare on ecocide should also be emphasized. The two World Wars of the twentieth century overshadow the many other wars that have taken place, including the Korean War, the Vietnam Wars, the genocides in Eastern Europe and Central Africa. However, these were all important contributors to modern ecocide. The following diagram gives a clear picture of the escalation of warfare (Broswimmer 2002:127):

Table 13: Wars and war deaths, ${ }^{i} 1500$ to 2000

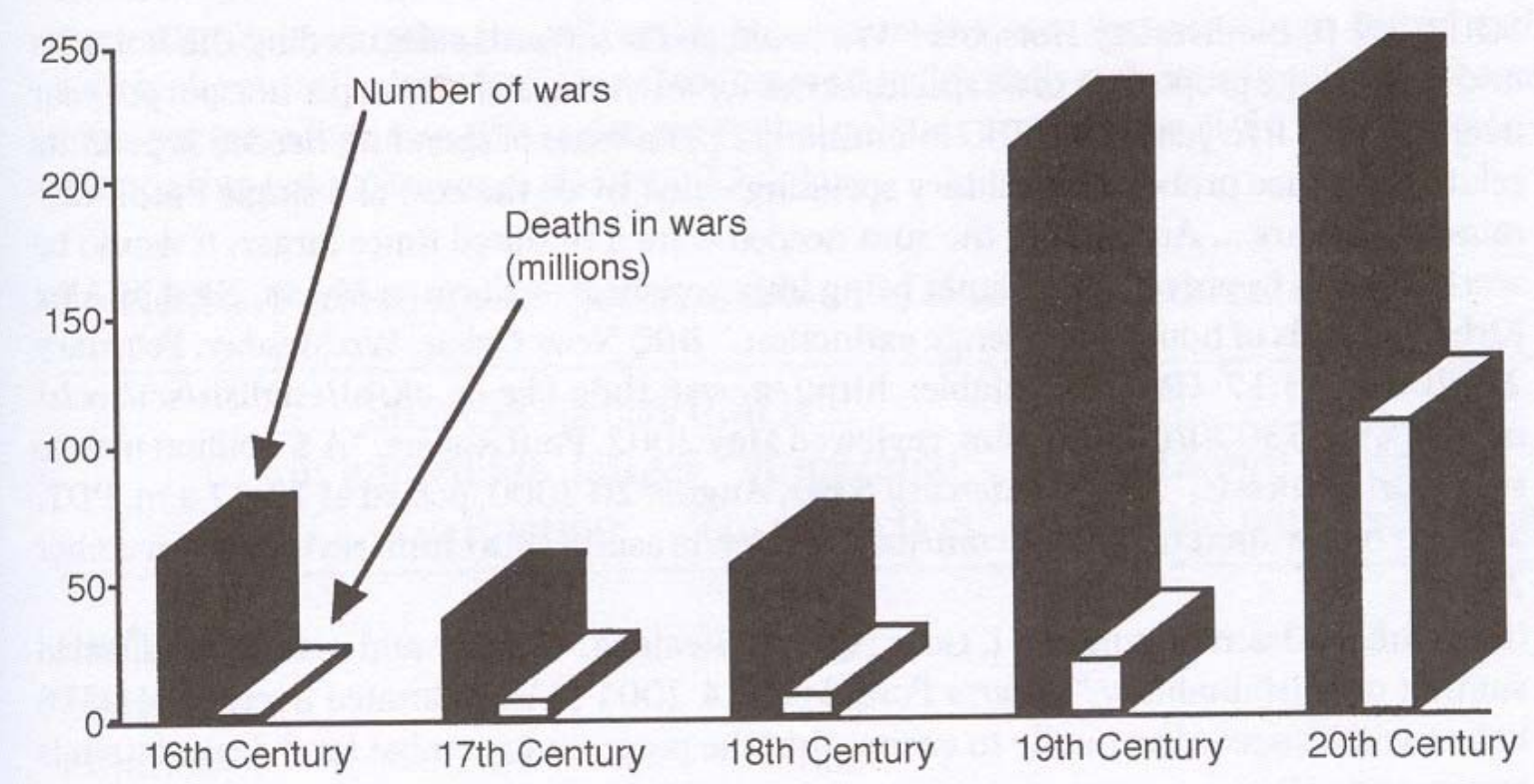

The ecocidal influence of warfare can be illustrated by Broswimmer's (2002:76) overview of the situation in Vietnam.

Current trends of globalism add further contributing factors to modern ecocide. Firstly, mega companies have become so big that their international sales often exceed the GDP of entire nations. The mere magnitude of these companies makes it virtually impossible for governments to contain them. It becomes difficult to enforce laws regarding ecological conservation onto these companies. Secondly, globalization has been proved to promote poverty and poverty leads to the destruction of ecosystems by people in order to provide in their needs. Thirdly, globalism gives rise to nationalist, fundamentalist and paramilitary movements and increasingly these groups may get access to nuclear, chemical and biological weaponry which in itself poses a major threat to the ecosystems. 
These factors make evident the destruction of the habitat of all living species in the modern age. Deforestation continues at an alarming rate and global warming changes climates. McCormick and Connors (2002:215-216) refer to studies that indicate clearly that the 1990's was the warmest decade on record, that the earth's surface temperature has increased about one degree Fahrenheit in the last century and that this situation has accelerated since 1979 . We can expect even more rapid warming trends and the doubling of carbon dioxide levels in this century. This will inevitably lead to floods, droughts and heat waves. Every year consumers and industries burn an amount of fossil fuels that took a million years to produce. The expectation is that the world will run out of petroleum in forty years and natural gas in sixty years.

A consideration of the role of Christianity in this destructive process needs to be part of the debate about the cause and magnitude of ecocide. What role did Christianity play in this? Since the publication of the influential article by White (1967:1203 see also Hallman 1995:6 and Kässmann, 1995:28) many scholars agreed with him in his assessment that Christianity is partly to blame for the ecological crisis as it developed in modernity. He (White 1967:1205) blames the story of creation and says: "Mankind named all the animals, thus establishing his dominance over them. God planned all of this explicitly for mankind's benefit and rule: no item in the physical creation had any purpose save to serve mans' purpose. And, although mankind's body is made of clay, he is not simply part of nature; he is made in God's image. Especially in its Western form, Christianity is the most anthropocentric religion the world has seen".

Loader (1987:9) also concludes that Christianity created a dualism between humankind and nature and nature was relegated to something of a second degree. As is the case with White, he maintains that Christianity does have a burden of blame to bear for what has happened to nature.

One can differ with White about the interpretation of the story of creation and the command given to humankind by God, but it will be fair to say that Christians have to admit that the deist worldview in particular played an important part in the degradation of nature and the role of humankind as ruler over creation. Although the term can not be defined in such a way that it includes all its advocates, the 
definition of Veldhuis (1999:788) summarizes the main idea of this worldview. He maintains that deism became the philosophical position in the eighteenth century to the effect that God is the Creator but he does not intervene in nature or history. Philosophers such as Newton, Locke and Hume saw the world as a giant clockwork wound up by God which God left behind for humankind to use. The entrepreneur, merchant, scientist and industrialist became the counterparts of God. The whole of nature was seen as a mere resource for commercial exploitation ${ }^{2}$. The upsurge in scientific research produced many positive results in the sense of the improvement of human life, but technology and the new ways of warfare also had tremendous negative effects on nature. Resources became commodities and populations and ecosystems were disrupted. The full impact of the Industrial Revolution in the midnineteenth century accelerated the pace of global ecological destruction. This period saw the emergence of what Abraham (1995:66) termed the "paradigm of growth" which entails the use of enormous capital and the exploitation of natural resources, particularly non-renewable ones for the sole purpose of growth.

\section{A CHRISTIAN ETHICAL PERSPECTIVE}

Due to the process of ecocide in modern times, environmental ethics has become a major topic also in modern Christian ethical reflection. How should Christian ethics deal with this issue? In his attempt to respond to the negative perception about Christianity's possible contribution to ecocide in the third phase of the etiology of ecocide, Moltmann (1993:21) pleads for a new theological doctrine of creation that can take up environmental issues. His perspectives are enriching because they elevate the doctrine of creation to a useful paradigm in environmental ethics. Essential in this approach will be the necessity to understand creation not just as nature but as God's creation and to respect it as such because creation will be the home of God. There is a divine transcendence but also immanence in the relation God and creation. This view is indeed a valuable angle of approach $^{3}$. The following reflection about the relevant biblical

2 An excellent review of the development of Deism in this historical context is provided by Walker (1992:579).

3 See Bouma-Prediger (1997:79). In spite of his critique on some of Moltmann's views on God and creation which is worthy of consideration, Bouma-Prediger says that Moltmann's persistent affirmation that Christian 
guidelines for ethical purposes is an attempt to make a contribution to this contextual understanding of creation with regard to ecology.

\subsection{Biblical guidelines}

\subsubsection{God and creation}

The biblical narrative of creation teaches that God has created heaven and earth and all its inhabitants out of nothing ${ }^{4}$. Although the Bible story speaks of the creation as "sudden events" in the space of six days the meaning of a day ought not to be seen as a day of twenty-four hours as is accepted in biblical creationism. Modern paleontology proofs that creation has taken millions of years by way of an astonishing process of development and evolution. Therefore it is more responsible to take the view of progressive creationism which accepts the idea of a continuous formative history of inanimate structures over many thousands and millions of years but still posits the existence of gaps in the developmental economy of the biotic world. The "day" in Gen. 1 can be seen as a moment in the "timeframe" of God (Van Till 1999:715). Besides, for him one day is like a thousand years and a thousand years like one day.

In the description of the creative work of God the phrase "And God saw it was good" appears several times. It was not only good in the eyes of God but it also reflected God's glory and wisdom. The world is charged with the grandeur of God. The Bible speaks of God's hiddenness in creation (Job. 38 - 41) and his continuous providence. The relationship of God and his creation manifests itself as divine preservation (conservation), the influencing of causes in

theology must take with equal seriousness both divine transcendence and immanence must be considered as one of his most significant contributions to the doctrines of God and creation. I also regard this view as an important contribution especially in the development of a much needed contextual Christian environmental ethics.

4 The whole issue of creation has become a topic of discussion in Old Testament theology since the Enlightenment. See for example in this regard Von Rad (1984:53-64) and Westermann (1984:90-102). Up to now all the controversies regarding the narrative of creations are far from settled. This article does not intend to enter into this debate or to evaluate the various arguments posed in the Old Testament theological debate. It will argue from the presupposition that God's creative actions are real. From this premise the focus will be on the implications of God's creation for the ecological crisis today. 
the world (concursus) and world sovereignty (gubernatio) (Van Till 1999:723). One of the major Reformed Confessions, the Heidelberg Catechism, explains the doctrine of the providence of God as follows: "The almighty and everywhere present power of God; whereby, as it were by His hand. He upholds and governs heaven, earth, and all creatures; so that herbs and grass, rain and drought, fruitful and barren years, meat and drink, health and sickness, riches and poverty, yea, and all things come, not by chance, but by His fatherly hand (Ac 17:25-28; Heb 1:3; Jr 5:24; Ac 14:17, Jn 9:3, Pr 22:2; Job 1:21; Mt 10:29-30; Eph 1:11)" (Beeke \& Ferguson, 1999:42).

Creation was thus not a single completed act of God as was professed by deism in the eighteenth and nineteenth centuries. A very influential motif in the doctrine of creation has always been that of the providence of God. For example, He restored his creation after the flood. The dove returned to Noah with a green olive twig. This is a sign of the greening of the earth once more. According to Anderson (1984:10) this was a sign that the earth became a permanent habitat for human and non-human creatures owing to God's pledge to maintain the constancy of the natural order. God has created everything and still maintains his creation. Any notion of the absence of God in creation and the freedom of humankind as the ruler of nature with the divine right to exploit nature without limits has no biblical foundation (Loader 1987:16). The deist worldview presented an erroneous way of viewing God's creation and his providence. This distortion becomes even more clear when one shifts the focus to the calling of humankind in creation.

\subsubsection{Humankind and creation}

The first major factor revealed in the story of the creation is that humankind is an integral part of the creation. McCormick and Connors (2002:235) stress this important point in their application of biblical themes to environmental ethics. The Scripture reveals in Gen. 2 that humankind is part and parcel of the created order. Humankind was made from the same soil and clay God used to create the plants and the trees that cover the earth. Humans are not elevated above creation or called to function outside creation. As is explained in Job 38 and 39 and in Psalm 104 humankind exists alongside all God's other creatures. As part of creation humankind depends solely on God for protection and care. The authors also refer to the doctrine of salvation in the New Testament where it is stated 
that it is not only humankind that will be redeemed through the sacrifice of Christ but that the whole creation will be renewed or recreated. Paul wrote in Romans 8:21 that not only humankind, but the rest of creation sighs now under its bondage to mortality but will eventually be liberated from its bondage to decay and brought into the glorious freedom of the children of God.

As an integral part of creation and since he is created in the image of God, God has given humankind the cultural mandate in Gen. 1:28: "God blessed them and said: 'Be fruitful and increase in number; fill the earth and subdue it. Rule over the fish of the sea and the birds of the air and over every living creature that moves on the ground".

This instruction is repeated in Genesis 2:15 when God put humankind in the garden of Eden to work on it and take care of it. After the Fall in the story of Noah God again commissioned humankind with the cultural mandate (Gn 9:1-3) (see Schilder 1953:56 and Douma 1966:166). Genesis uses strong language and the words used for "subdue" and "rule" give the impression of "trample on". That is why authors such as White accuse Christianity of being responsible for the ecological crisis today. Whereas other pantheistic religions deifies nature, it seems that Christianity elevates humankind to rule over nature. However, such a conclusion is not valid, because the commission to rule implies service. The word culture stems from the Latin "colere" which means "to build" and "to care" for (Schilder 1953:50). The Christian concept of ruling is to serve well (Geisler 1989:302; see also Keitzar 1995:55). In this process humankind is in service of God, like Christ who ruled by serving (Mk 10:45; Phlp 2:5-8).

Taking into account other biblical passages it becomes clear that the cultural mandate must be carried into effect in a responsible way and that means that humans must care for creation. Cunanan (1995:15) refers to one of these important passages in his reflection on the relevance of the prophecy of Joel for environmental awareness. He concludes that this prophet outlined a seven point programme for environmental-developmental awareness and action. These are:

- $\quad$ awareness of the ecological situation;

- a call to mourning, lamentation, repentance (change in value and lifestyles); 
- $\quad$ organizing people along environmental and spiritual concerns;

- a warning of impending judgment and destruction;

- restoration and renewal of the environment and society;

- defining people's participation and roles in the transformation of society;

- $\quad$ addressing the political, economic and social components of the ecological and development agenda.

In his analysis of Biblical evidence Moltmann (1993:21) also says that the biblical charge is a dietary commandment. Human beings and animals alike are to live from the fruits which the earth brings forth in the form of plants and trees. In spite of the God given right to use animals and plants God also teaches humankind to respect living things. Jonah's expectation that Nineveh would be destroyed was different from God's, who also thought of the 120,000 people and the animals living in that city (Jonah 4:11). Humankind is taught to care for animals. Animal abuse is, from the Bible's viewpoint, an abomination. If your enemy's ox or donkey wanders off you have to take it back to him. The righteous person cares for the needs of his animals ( $\operatorname{Pr} 12: 10)$. He knows also that an animal must be able to rest on the Sabbath (Ex 20:10; 23:12), and that a threshing ox may not be muzzled (Dt 25:4). Israel was also not permitted to do whatever she wanted to the trees, since when she besieged an enemy's town, she was not allowed to destroy the groves around the town (Douma 1996:209). In the seventh year also the land should rest (Dt 23:10).

The sixth commandment has an environmental aim. Taking into account the synecdoche character ${ }^{5}$ of the Ten Commandments it is fair to say that this commandment prohibits more than taking human life. It commands respect for all life created by God - the life of humankind, animal and plant. Human dominion must correspond with the care the Creator has for his creation and especially for every

$5 \quad$ See in this regard De Bruyn (1998:16). He explains this concept as follows: "Synecdoche is a figure of speech in which the whole is indicated by a part. A part is indicated, but the whole is intended. A clear example of this is found in the fourth request of the Lord's Prayer. There we literally pray for 'our daily bread', but we actually intend to ask God 'to take care of all our physical needs'. This includes, apart from bread, all other kinds of food, as well as clothing and other vital needs". 
living creature. It is fair to say that the destruction of nature is seen in the Bible as humankind's revolt against God. Therefore, the imperative of lamentation, repentance and conversion implies not only a restoration of the relation with God and fellowmen, but also with creation.

In conclusion, the concept "cultural mandate", as embodied in the full biblical context, entails that humankind has the privilege to utilize creation for his own good, but that he has the responsibility to take good care of everything God has created. The execution of the cultural mandate is subject to many other biblical norms. Humankind has to rule in harmony and not in hostility. Moltmann (1993:21) indicates that the rule of humankind has nothing to do with the "dominium terrae". Humankind may use creation for its own survival but he has the calling to care for creation as a steward of God. In fulfilling its calling humankind is responsible to God himself. Use may never become abuse. Therefore, to interpret Genesis 2:15 and 9:1-13 without the context of the whole biblical revelation may indeed lead to the erroneous conclusion that the cultural mandate implies dominion without responsibility. Such an interpretation is a distortion of the Christian message regarding the divine calling to care for the environment

\subsection{Ethical guidelines}

Ecocide as a very disturbing modern ethical problem has become a widely discussed issue in Christian ethics in virtually all the Christian traditions. This is evident in various statements of Ecumenical bodies inter alia the documents of the World Council of Churches, the 1987 encyclical of the pope entitled "On social concern", and the Evangelical Lutheran social statement entitled: "Caring for creation (Granberg-Michaelson 1995:96). Many documents regarding the ecological crisis have also been issued in the sphere of Eastern Orthodox tradition (Efthimiou 1995:92). These documents and the views of many contemporary ethicists challenge humankind to move beyond "anthropocentrism" (or "homocentrism") in dealing with creation to "ecocentrism" which acknowledges humankind's interconnectedness and mutual interdependence with creation (McCormick \& Connors 2002:239). In the pursuance of this movement one will have to deal with the notion of neutral science and the responsibility of humankind to God in the exploitation of his creation. 


\subsubsection{No neutral science with humankind in the centre}

The notion of neutralism in science should be addressed when dealing with ecocide. Before the influence of Kuhn in the philosophy of science, positivism proposed the idea of neutral science. In this positivistic paradigm science was defined as an objective method of research in the exploitation of creation for the benefit of humankind and human prosperity. Sciences emancipated themselves from the religious cosmology (Moltmann 1993:33). This philosophy of science created an optimistic view of the abilities of humankind to exploit and to create the terrain that was his to work. Science has been exercised in an anthropocentric way. But this was exactly where the root cause of the misuse of science in the third wave of the etiology of ecocide was hidden. Kuhn (1970:VIII) has proved that science can not be practiced neutrally or objectively because there will always be a leitmotiv as a presupposition. In the period of positivistic science humankind itself and its needs, pleasures, development and self-centric ideals formed part of presupposition. Science was done by humankind for humankind. Humankind itself became the only benefactor in science.

The new post-foundational philosophy of science acknowledges the subjectivity of science namely that science is driven by paradigms that can differ from time to time and place to place. There is no such a thing as a value-free science (Moltmann 1993:25). This philosophy entails that more than humankind's needs becomes the focus of science such as the total creation which includes ecosystems and the mutual relationship between humankind and nature. The post-foundational view of science is more ecofriendly and should be promoted in the philosophy of science over and against anthropocentric worldviews. Young scientists should be educated to see that humankind is there for creation and not creation for humankind.

Moltmann (1993:34) proposes an Ecological Theology of nature wherein theology and science arrive together at an ecological awareness of the world. He is convinced that theology and science: "have become companions in tribulation, under the pressure of the ecological crisis and the search for the new direction which both must work for, if human beings and nature are to survive at all on this earth. It is only slowly that theologians are beginning to see that their continual attempts to draw dividing lines between theology and 
the sciences are no longer necessary, because science's earlier unquestioning faith in itself has disappeared".

The post-foundational view of the relation paradigm and science promises to provide a new concern about ecocide and a relevant ethics regarding environmental issues. This development can be seen as a break-through in the challenge to the destructive role played by the idea of neutral science with its anthropocentric scientific ideals and injurious scientific practices. Furthermore, it elevates ecology to the same level as technology and paves the way for a sound balance between the two.

\subsubsection{To the benefit of humankind or in the service of God?}

The biblical perspectives indicated above lead us to speak of a theocentric approach rather than an anthropocentric or an ecocentric approach. A theocentric approach entails that caring for the ecosystems should be part and parcel of religion. According to McCormick and Connors (2002:220) three models regarding the relation humankind and creation can be discerned in Christian tradition. The first is the "kingship model" which pertains that humans are to subdue the earth and have dominion over all things. The locus classicus proposed for this view is Gen. 1:28. These authors are critical towards this model and refer to Johnson's view where she says that "(this model) sees humanity separated from the earth and placed in a position of absolute dominion over all other creatures who are made for us. In this view, the creatures of the world are ranked ... with greater value being assigned to those up on the great chain of being ... In the progression from the pebble to the peach to the poodle to the person, with women somewhere between the latter two, the higher order of creatures has the right to use and control the lower ... This is the patriarchal pyramid again, resulting in a top-down domination of nature by mankind".

The authors describe the second model as the "stewardship model". This model continues with the structure of "hierarchical dualism" but entails further that human beings should be responsible caretakers or guardians of creation. They refer to statements of the US catholic bishops in 1991 and the Evangelical Lutheran Church in America's in 1993 to prove their statement that this stewardship model is the view held in most mainline Christian traditions. Their assessment is probably correct. However, they argue with Johnson that although this model is a better articulation of the view of 
Scripture, it does not delve deeply enough to articulate what the relation between humankind and creation should be.

The third model can be described as the "kinship model". With reference to Johnson and the Roman Catholic authors Himes and Himes, McCormick and Connors (2002:222) describe this model in the words of Johnson as follows: "If separation is not the ideal but connection is; if dualism is not the ideal but the relational embrace of diversity is; if hierarchy is not the ideal but mutuality is; then the kinship model more closely approximates reality. It sees human beings and the earth with all its creatures intrinsically related as companions in a community of life ... This kinship attitude does not measure differences on a scale of higher or lower ontological dignity but appreciates them as integral elements in the robust thriving of a whole".

Arguing from the perspective of the cultural mandate against the background of a theocentric approach it is difficult to see the difference between the last two models. Humankind is called to be a steward in caring for God's creation. In the execution of this calling it is responsible to God and cannot act as a king on its own. Its duty will be to unfurl the beauty and the goodness of nature and to combat the remnants of sin that distorted the goodness of creation due to the Fall of humankind. A Christian ethics of life will entail that the relation between humankind and nature should be one of stewardship in service of God. This stewardship implies kinship over and against kingship because a theocentric approach renders any anthropocentrism null and void. Real theocentrism can lead to only one attitude: responsibility to God that will be expressed in humankind's care for its creation. A theocentric approach to nature may be the new worldview which rejects domination and replaces it with the alternative value system that Ruether (1985:535) requested in her critique on the concept of the domination of nature in classical Christianity.

Theocentrism means that humankind can benefit from the sources given by God but then creation must be utilized in such a way that its goodness and beauty should not be distorted or destructed. The maintenance of the honor of God and the image of his work in the integrity of creation exceed by far the needs of humankind. Humankind must seek the fine balance between the honor of God and the benefit of humankind. When this fine balance 
is found kingship will not endanger stewardship. True stewardship is expressed in Ps. 8 which describes the glory and the majesty of God and in the light thereof the task of humankind.

All human activity regarding the utilization of creation is subject to the acknowledgement and thus the maintenance of the glory of God as expressed in his wonderful creative work. Dealing with ecology is part and parcel of Christian religion. Irresponsible and anthropocentric exploitation and misuse of the God-given sources in nature amounts to disobedience to God and subsequently a rejection of one of the core issues of the Christian faith. In its caring for creation humankind should be more obedient to God than to its own egocentric needs. In this respect humanity must realize that there can be limitations to scientific research and the development of new technologies. Science can not have an open mandate regarding the exploitation of nature. Also the scientist is a steward and new inventions must be evaluated in the light of his calling to stewardship. Inventions that can benefit humankind but harm nature should not be patented and other means to reach the same benefit should be pursued. If alternatives are impossible to develop humankind must be willing to live without the promised benefits rather that to commit ecocide.

\section{A HUMAN RIGHTS PERSPECTIVE}

Viewing ecocide in the context of the human rights debate brings two important issues to light. These are, on the one hand, the relation between the protection of human rights today and the protection of the environment and, on the other hand the "rights of the next generation". These issues are considered in the following short reflection.

Research about the first issue proved that where human rights are violated ecocide will be an inevitable side effect. Various scientific reports showed that poor communities are usually living in areas with all kinds of hazardous waste which endangers their environments. Many of these communities receive little governmental protection in contrast with the more affluent communities (McCormick \& Connors 2002:241). The protection of the rights of the poor must include protection from this kind of discrimination.

But being poor in itself is also a contributing factor to ecocide. In poor countries people have to exploit nature to survive and their 
exploitation exceeds the boundaries of the cultural mandate. To curb ecocide poor communities should be developed in order to create a balance between nature and the population growth as well as to provide for other sustainable sources of an "eco-friendly" survival. Because ecocide is a global threat the eradication of poverty should be regarded as a global challenge. Ecocide in Africa, for example deforestation in the tropical regions for purposes of energy, is also a threat to "first world" countries in the "Northern Hemisphere". Promoting the ideas of democracy world wide as well as good and responsible economic policies, peace, development and the ethos of human rights is not only good for many pressing problems in the world but also for the protection of the all important ecosystems.

The limitation of certain rights in favor of other rights in order to deal with the issue of ecocide effectively can also be raised in this critical area of the human rights debate. For example: when it becomes clear that an industrial development will be hazardous to nature and sensitive ecosystems, it can be prohibited. The rights to free economic trade, freedom of movement, freedom of choice of an occupation and rights regarding labor relations must then be limited in favor of the right to a healthy environment and the right to access to food and clean water.

Researchers often speak nowadays of the "rights of the next generation". With this expression they want to highlight the second important issue regarding ecocide in the human rights debate. What is our responsibility today for the next generations? A Christian ethical perspective entails that stewardship also means looking at the future. It is especially true in the field of scientific research. Scientific research has the responsibility to look at the long term effects of new inventions. The pollution we experience today is in some respects the result of short sighted scientific research in the past. Did nuclear scientists really foresee the devastation that would be caused by nuclear waste and the misuse of this technology? Was it really worthwhile to proceed on the road of nuclear research? These questions must be asked today in view of the huge explosion of technology and genetic research: what will be the long term effects and will it be responsible to future generations to proceed with this although it has certain benefits for humankind?

In this respect the role of government is important. Besides having a good human rights perspective every government should 
have a well defined "green policy" which will not only outlaw developments and actions that will be harmful to the environment and to all citizens, but that will have the capacity to be the watchdog over the development of science and technology. For example such a policy should prevent government to allow the exportation or importation of arms that can damage ecosystems beyond repair as was done by the US in the Vietnam war and as is done by many countries today in their development and testing of nuclear and biological weapons. To realize a responsible green policy, the "rights of the next generation" should be defined as fundamental rights in the Bill of Rights of a Constitutional Democracy. Such a step will give individuals the opportunity to act in a constitutional court against governments and mega-corporations where the rights of the future generation are at stake because of destructive policies or actions regarding the environment. The Court of Human Rights in Strasbourg gave an example of how these rights can be implemented with its ruling that the Spanish government should pay damages to an individual because of environmental pollution (Arthur 1994:1-6).

\section{PRACTICAL GUIDELINES TO DEAL WITH ECOCIDE}

The overall picture of ecocide and the urgency to avoid any further disruption of nature and its sources should not be a matter of concern for governments only. Society as a whole should also become deeply involved. The first step should be a planned process to promote an awareness of the problem. In this process education in environmental ethics alongside ecology can play a very important role. Consumers, stockholders, board members, employers, scientists and developers must be educated to give priority to these questions: how their planned experiment, development or purchase would influence the environment and how their actions today would bear on the basic rights which their descendants will also want to enjoy. McCormick and Connors (2002:224) provide simple but important ways to promote and to establish a constant awareness of the problem. Their proposals will be further discussed along with other ideas in the following paragraphs.

\subsection{Educators}

In this category one can speak of the important role of parents and teachers. In the home among the family and in the school children start their learning process and it is here, in the early stages of the 
learning process, that they have to be taught to be responsible stewards in God's creation.

However, the purpose of this education should not only lead to more information about nature, but should lead to a transformation of the anthropocentric worldview and new value systems regarding human responsibility to be good stewards in God's creation ${ }^{6}$. Respect for the integrity of creation and nature should be included in school curriculae as early as possible especially for children living in heavily populated urban areas where accessibility to the natural environment is limited.

\subsection{Corporations}

Employers, developers, board members and stockholders can all exercise important roles in the conduct of corporations with regard to the protection of ecosystems. Huge corporations harm the environment in many ways through their mining, harvesting, manufacturing, delivery and disposal. They are major consumers of energy and other resources, polluters of water, land and air and major producers of toxic waste and garbage. Their destructive actions regarding the environment are evident in the huge industrialized countries but even more so in the developing countries where the need for investment and development often gives them a free hand to conduct their business without restraints. They also harm the environment in another way when they exploit labor by paying wages below the subsistence level, thereby contributing to the ongoing cycle of poverty and environmental degradation (Geisler 1989:230).

The people in charge of corporations and the people benefiting from its actions are the ones that should feel responsible to find the balance between production on the one hand and the protection of the environment on the other. They must develop their policies and direct their investment in such a way that both development and environment are served. Every company should have the policy to

6 Geisler (1989:197-298) rejects the notion of education for the sake of mere information about the problem. He regards this solution as an out-dated Platonic premise. His plea for education for the sake of a change in value systems is noteworthy because education from an anthropocentric presupposition can not deal with the ecological crisis and will only condone the destructive process of the last two centuries. 
conduct an environmental impact study before they begin with manufacturing, harvesting or mining. And a part of their profits should be allocated to the restoration of the environment they may harm in the process of production. These are especially crucial in the developing world where governments are not fulfilling their duties to protect the environment.

\subsection{Churches}

Churches are important moral decision makers. It is fair to say that churches have the capacity to raise an awareness of the environmental situation we face. This is true and as is the case in many other fields in ethics, churches can contribute to a general awareness of the destructive effects of ecocide. Apart from promoting a theocentric worldview according to Scripture, many other issues relating to the protection of the environment can be attended to by churches on the local level. Among these issues are the development of awareness that the population growth is too high and that this phenomenon is detrimental to the need for protection of the environment.

The conscience of people can also be sharpened to deal with destructive attitudes such as the consumption explosion, consumerism, excessively affluent lifestyles and avoidance of the plight of the poor and the needy. The community must be taught that it is immoral to spend the world's renewable resources at a faster rate than these resources can be replaced. In the ecumenical field the Church can act as the watchdog over environmental affairs and as the conscience of the communities without intervening in the affairs of governments. At least, the change from a culture of environmental exploitation to a culture of caring for nature must start with a change in the attitudes of people ${ }^{7}$. In this regard the churches are excellently equipped and situated.

7 In an illuminating article Conradie (2003:131) pleas for more than just awareness. He is of the opinion that the Church must provide a new moral vision for society by designing a true ecological theology that will be more than environmental ethics or a revisited theology of creation. Conradie's viewpoint is worthwhile especially in the sphere of world-denying theologies. But the question can be raised whether such an ecological theology will not become just another modern-day genitive theology such as the many political theologies of the past three decades? For this reason I choose for the concept of 


\section{CONCLUSION}

Moltmann (1993:25) is to the point with his warning that there is often a resistance to an acknowledgement of the ecological crisis in our societies which actually contributes to the spread and deepening of that very crisis. People tend to make light of it, talking of the "strains on the environment" and the regrettable "side-effects of modern technologies". He then continues: "The airy assumption is that the ecological crisis can be solved by technological means. But minimizing the crisis does not merely suppress the pain the crisis causes; it is also a way of pushing aside the necessary transformation of the whole system of living. The result is that people are becoming increasingly apathetic about the slow death of nature. Even the human will to live is threatening to swing over into a death wish, since in this crisis of the whole system, human affirmation of life is not possible without a complete change of direction. Only life systems that are capable of suffering are capable of surviving, because they are the only ones that are prepared to learn and are open to change and renewal."

The time has come for Christian ethics and especially the human rights debate to pave the way for this change of direction.

\section{Consulted literature}

Abraham, K C 1995. A theological Response to the Ecological crisis in Hallman, D G (ed.). Ecotheology. Voices from South and North. New York: Orbis Books, 65-78.

Anderson, B W 1984. Creation and Ecology in Anderson, B W (ed.). Creation in the Old Testament. London: SPCK.

Anderson, B W 1984 (ed.). Creation in the Old Testament. London: SPCK.

Arthur, R 1994. Environmental rights. Lancet, 344, 1-6.

Beeke, J R \& Ferguson, S B 1999. Reformed Confessions harmonized, with annotated bibliography of Reformed doctrinal works. Grand Rapids: Baker Books.

Bouma-Prediger, S 1997. Creation as the Home of God: The Doctrine of Creation in the Theology of Jürgen Moltmann, Calvin Theological Journal 32(1), 79.

-, 2001. Environmental Ethics in Fahlbusch, E et. al., The Encyclopedia of Christianity, Volume 2. Leiden: Brill.

the cultural mandate as a principle for a contextual environmental ethics based on traditional Reformed theology. 
Broswimmer, F J 2002. Ecocide, A Short history of Mass Extinction of Species. London: Pluto Press.

Conradie, E M 2003. How can we help to raise an environmental awareness in the South African context? Scriptura 82(1), 131.

Cunanan, J P M 1995. The prophet of Environment and Development in Hallman D G (ed.). Ecotheology. Voices from South and North. New York: Orbis Books, 13-72.

De Bruyn, P J 1998. The Ten Commandments. Potchefstroom: Potchefstroom University for Christian Higher Education.

Douma, J 1966. Algemene genade. Goes: Oosterbaan \& Le Cointre.

-, 1996. The Ten Commandments. Phillipsburg: P \& R Publishers.

Efthimiou, M B 1995. Orthodoxy and the Ecological Crisis in Hallman D G (ed.). Ecotheology. Voices from South and North. New York: Orbis Books, 92-95.

Geisler, N L 1989. Christian Ethics. Options and Issues, Grand Rapids: Baker Book House.

Granberg-Michaelson, W 1995. Creation in Ecumenical Theology in Hallman D G (ed.). Ecotheology. Voices from South and North. New York: Orbis Books, 96-106.

Hallman, G G (ed.) 1995. Beyond "North/South Dialogue in Hallman D G (ed.) Ecotheology. Voices from South and North. New York: Orbis Books, 312.

Kässmann, M 1995. Covenant, Praise and Justice in Creation, Five Bible Studies in Hallman D G (ed.). Ecotheology. Voices from South and North. New York: Orbis Books, 28-51.

Keitzar, R 1995. Creation and Restoration, Three Biblical reflections in Hallman D G (ed.). Ecotheology. Voices from South and North. New York: Orbis Books, 52-64.

Kuhn, T S 1970. The Structure of Scientific Revolutions. Chicago: The University of Chicago Press.

Loader, J A 1987. Image and Order: Old Testament perspectives on the ecological crisis, in Vorster W S (ed). Are we killing God's earth? Ecology and Theology. Pretoria: University of South Africa.

McCormick, P \& Connors, R B 2002. Facing Ethical Issues, Dimensions of Character, Choices and Community. New York: Paulist Press.

Moltmann, J 1993. God in Creation. Minneapolis: Fortress Press.

Parent, R J 2003. Mission communicate. Unpublished Ph.D. thesis. Pretoria: University of South Africa.

Ruether, R 1985. Feminist theology and ecology in Gill R (ed.). A Textbook of Christian ethics. Edinburgh: T \& T Clark.

Schilder, K 1953. Christus en Cultuur Franeker: Wever. 
Van Till, H J 1999. Creation in Fahlbusch E et. al. The Encyclopedia of Christianity 2, 715. Grand Rapids: William B Eerdmans.

Veldhuis, R 1999. Deism in E Fahlbusch (ed.). The Encyclopedia of Christianity, volume 1, 788. Leiden: Brill.

Von Rad, G 1984. The Theological problem of the Old Testament in Anderson B W (ed.). Creation in the Old Testament, 53-64. London: SPCK.

Walker, W 1992. A history of the Christian Church. Edinburgh: T \& T Clark.

Westermann, C 1984. Biblical Reflection on Creator-Creation in Anderson B W (ed.). Creation in the Old Testament, 90-102. London: SPCK.

White, L 1967. The historical roots of our ecological crisis. Science. (155) $3767,1203$.

Wilson, B G 1988. Records of our history, Colonial identities - Canada from 1760 to 1815. Ottawa: Ministry of Supply and Services. 